\title{
Optimization of Dynamic Binding Capacity of Anion Exchange Chromatography Media for Recombinant Erythropoietin Purification
}

\author{
Mina Sepahi ${ }^{1,{ }^{*}}$; Hooman Kaghazian ${ }^{1}$; Mina Payravi Sereshkeh ${ }^{1}$; Tahereh Sadeghcheh ${ }^{2}$; \\ Shahin Hadadian ${ }^{2}$; Mohammad Reza Jebeli ${ }^{1}$; Fereshteh Yavari ${ }^{3}$ \\ ${ }_{1}^{1}$ Recombinant Biopharmaceutical Production Department, Research and Production Complex, Pasteur Institute of Iran, Karaj, I.R. IRAN \\ ${ }^{2}$ Quality Control Department, Research and Production Complex, Pasteur Institute of Iran, Karaj, I.R. IRAN \\ ${ }^{3}$ Science and Research Branch, Islamic Azad University, Tehran, I.R. IRAN \\ ${ }^{*}$ Corresponding author: Mina Sepahi, Recombinant Biopharmaceutical Production Department, Research and Production Complex, Pasteur Institute of Iran, Karaj, I.R. IRAN. Tel: \\ +98-2636100983, Fax:+98-26361001642, E-mail: msepahi56@yahoo.com
}

Received: January 3, 2014; Revised:January 26, 2014; Accepted: March 2, 2014

\begin{abstract}
Background: The dynamic binding capacity (DBC) of a chromatography matrix in protein purification is the amount of the total protein absorbed into the matrix, before occurrence of a significant break in the breakthrough curve. Optimization of the process criteria for maximum DBC avoids extra process scale-up and reduces the processing time, costs and protein loss. Taguchi method is a simple useful tool in experimental design to estimate the optimal condition with minimum experiments.

Objectives: In this research, linear flow rate, $\mathrm{pH}$ and protein concentration of the feed were checked according to an L9 orthogonal Taguchi array, to estimate the best conditions for maximum DBC of Q-sepharose fast flow (QSFF) resin in recombinant human erythropoietin purification process.

Materials and Methods: A crud sample containing human recombinant erythropoietin was harvested from a cell culture of Chinese hamster ovary (CHO) cell line. Desalted harvests with different total protein concentrations $\left(30,40\right.$ and $\left.50 \mu \mathrm{g} \cdot \mathrm{mL}^{-1}\right)$ and $\mathrm{pH}$ values (5, 6 and 7) were loaded into a packed column of QSFF with different linear flow rates $\left(60,120\right.$ and $\left.280 \mathrm{~cm}^{-1} \mathrm{~h}^{-1}\right)$ up to $10 \%$ of the breakthrough curve. The total protein loading to the column was checked by UV absorbance and Lowry method, and erythropoietin concentration was measured by ELISA. Analysis of variance (ANOVA) was applied to determine the optimum condition.

Results: Finally, total protein concentration of $50 \mu \mathrm{g} \cdot \mathrm{mL}^{-1}$, pH of 5 and flow rate of $120 \mathrm{~cm} \cdot \mathrm{h}^{-1}$, were anticipated as the optimal process conditions with $5.85 \mathrm{mg} \cdot \mathrm{mL}^{-1}$ of resin as the dynamic binding capacity.

Conclusions: Experiments with anticipated optimal criteria were performed three times and no significant difference was observed ( $p=$ 0.136 , and $6.06 \mathrm{mg} / \mathrm{mL}$ as the average dynamic binding capacity).
\end{abstract}

Keywords: Binding Capacity; Ion Exchange Chromatography; Recombinant Human Erythropoietin

\section{Background}

Dynamic binding capacity (DBC) of a resin is the amount of absorbents that bind to the resin under operational conditions, before the partial saturation of resin occurs. Breakthrough curve shows the resin saturation profile (1) and the amount of absorbed protein at $10 \%$ of the curve is usually considered as DBC (2-7). Capacity of an ion exchange resin may be expressed as total ionic capacity, available capacity, or dynamic capacity (8).The actual amount of protein that can be bound to a resin under defined experimental conditions is called the available binding capacity of the gel $(1,9)$. If the defined conditions include the flow rate, the capacity is called the DBC (10). Frontal analysis is usually used to determine the binding capacity $(2,10,11)$. In frontal analysis experiments, the sample is injected to the column for a period of time. As long as absorbent is on the stationary phase, its concentration in the output effluent is zero. Once the stationary phase is saturated, absorbent concentration in the output effluent reaches to its inlet concentration $(10,12)$. The target protein can bind to resin, but undesired proteins do not bind and pass the column during the sample application. Therefore, absorbance rises and makes a continuous peak called "flow through plateau". The maximum product binding capacity is important to enable economic processing (13-15). The experimental conditions affecting the observed capacity of an ion exchange resin are: $\mathrm{pH}$, ionic strength of the buffer, nature of the counter-ion, flow rate, and temperature $(2,7,8,16$ 20). Flow rate is important for dynamic binding capacity. A flow rate between 100 and $400 \mathrm{~cm} \cdot \mathrm{h}^{-1}$ is usually recommended for ion exchange chromatography (8), considering that high flow rates will decrease the resolution (21, 
22). Capacity varies from case to case depending on the protein properties and flow rate, and all manufacturers have reported some data on DBC of certain proteins; for example, dynamic binding capacities of Q-sepharose fast flow (QSFF) resin for thyroglobulin and human serum albumin are 3 and $120 \mathrm{mg} \cdot \mathrm{ml}^{-1}$ of the gel, respectively (8). To optimize a chromatographic process, it is recommended to determine the DBC for the target protein. Optimization of the process criteria for maximum DBC leads to less need for excess process scale-up as well as decreased process time, costs and protein loss (2). Regarding the adsorptive properties, the optimum operational $\mathrm{pH}$ of a bind- and elute-mode ion exchange (IEX) process is characterized mainly in terms of selectivity and DBC of the resin. Selectivity and capacity do not always oppose, but rather complement each other. For example, eliminating more impurities in the flow-through, allows higher column capacity for the product because of availability of more binding sites (23). There are several methods for optimization of different process parameters, one of which is Taguchi method. In the 1920's, R.A. Fisher introduced a statistical method to study the effects of several variables of an experiment simultaneously, called DOE (design of experiments). Later in the late 1940's, Dr. Genechi Taguchi carried out a significant research with DOE techniques and introduced the Taguchi method in the USA in the early 1980's. The goal of Taguchi method is to determine and select the optimum condition by performing minimum experiments, in a way that the influences of noise factors on the system performance are kept at minimum levels. This technique uses the orthogonal arrays, variance, and signal to noise analysis (24).

\section{Objectives}

In this research, Taguchi-DOE method was used to determine the optimal conditions for achieving maximum DBC of QSFF anion exchange resin in the recombinant erythropoietin (EPO) purification process. EPO is a 166-amino acid glycoprotein with molecular weight of approximately $30.4 \mathrm{kDa}$, and is the main hormone involved in promoting red blood cell production in the bone marrow (25). Optimization of DBC was performed by investigation of the influence of three parameters including flow rate of sample application, $\mathrm{pH}$ of equilibration solution, and total protein concentration of the feed. Temperature and conductivity were constant in all experiments.

\section{Materials and Methods}

\subsection{Cell Culture and Sample Preparation}

The Sample necessary for performing the research was obtained from culturing Chinese hamster ovary $(\mathrm{CHO})$ cells (dihydro folate reductase or dhfr) producing re- combinant human EPO (rhEPO). Briefly, the cell culture process was performed using Dulbecco's modified Eagle's medium (DMEM, Gibco, Life Technologies, Grand Island, USA) supplemented with human recombinant insulin (Gibco, USA), and consisted of growth, expansion, recovery and harvesting phases. The collected supernatant was filtered by $0.2 \mu \mathrm{m}$ filtration cartridge (Sartorius, Gottingen, Germany) and preserved at $4^{\circ} \mathrm{C}$. A $10-\mathrm{kDa}$ poly ether sulfone module (Vivaflow 200, Sartorius, Gottingen, Germany) was used for ultrafiltration and the diafiltered harvest was used as the feedstock solution for further work. For this purpose, harvest was firstly concentrated up to the desired values at two bar pressure and its buffer was then exchanged by five volumes of the desired working buffers.

\subsection{Breakthrough Curve and Binding Capacity De- termination}

Anion exchange chromatography was performed on high-performance liquid chromatography (HPLC) system (Waters, Milford, USA). The QSFF resin was packed in XK-16 glass column (GE Healthcare, Uppsala, Sweden). Sodium acetate buffer $(\mathrm{pH}=5)$ was used as the equilibration buffer, and $2 \mathrm{M} \mathrm{NaCl}$ as the regeneration buffer. The total protein was measured by UV absorbance and Lowry method (26) and EPO concentration was analyzed by EPO ELISA kit (Roche, Basel, Switzerland). The partial purified harvest (clarified and diafiltered cell culture supernatant) was used as feed stock solution and some parts of the undesired protein did not bind to the resin and passed the column during sample application. Hence, the flow through peak was observed. Specific protein (EPO) concentration of the flow through effluent was measured by ELISA and any erythropoietin was detected. Temperature and conductivity were kept fixed at $4-8^{\circ} \mathrm{C}$ and $3-4.5 \mathrm{~ms}^{-\mathrm{cm}^{-1}}$, respectively, considering that most of the proteins are stable at $4^{\circ} \mathrm{C}$, although increasing temperature sometimes increases DBC (27) and low conductivity usually guarantees protein binding to the resin $(8,28-30)$. To determine the binding capacity, different samples (according to Table 1) were loaded into the column, up to $10 \%$ of the resin saturation. Afterwards, the column was regenerated with 2 $\mathrm{M} \mathrm{NaCl}$ solution. The flow through plateau and elution fractions were collected in different bottles and their total protein concentrations were calculated by multiplying their volumes by their protein concentrations (measured by Lowry method). To ensure that the flow through plateau did not mask the breakthrough curve, at first, $100 \%$ of the feed was loaded to the packed bed and resin saturation was performed with $50 \mu \mathrm{g} \cdot \mathrm{mL}^{-1}$ as the total protein concentration, with $\mathrm{pH}=5$ and 480 $\mathrm{cm} . \mathrm{h}^{-1}$ linear flow rate, to check all probable peaks and observe the peak of saturation state. To perform the selected treatments, less column volume was chosen to decrease the feed usage. 


\subsection{Factors and Levels to Investigate}

In this experience, according to packing conditions and real operational process criteria, the chosen levels for flow rate were 60,120 and $280 \mathrm{~cm} . \mathrm{hr}^{-1}$, and for the feed protein, concentrations were 30,40 and $50 \mu \mathrm{g} \cdot \mathrm{mL}^{-1}$. According to the isoelectric point of the target protein, the equilibration buffer $\mathrm{pH}$ was chosen at 5, 6 and 7. An L9 orthogonal array was chosen to design the treatments; thus, the concentration was chosen as factor one, flow rate as factor two, and $\mathrm{pH}$ as factor three. The criteria for all nine treatments and their results are shown in Table 1.

\section{Results}

During the saturation state (Figure 1), no peak overlap was observed, but the flow through absorbance was fairly high compared with that of desired proteins (section A), because of high concentrations of unwanted proteins. When most of the binding sites were occupied with the absorbed protein, resin was not capable to absorb more proteins; thus, unabsorbed proteins left the column and absorbance rise was observed in the chromatogram according to the resin saturation percent (section $\mathrm{B}$ ). Finally, the entire column was saturated and absorbance of the effluent was equal to the feed absorbance (section C). In this experiment, saturation was observed with a sharp rise in absorbance, because of the high flow rate.

The breakthrough curve of treatment one is shown in Figure 2. Chromatograms and breakthrough curves of other treatments are not shown. To check the saturation absorbance, the column was bypassed before starting each treatment, and the sample was passed through the UV detector. During the sample running for each treatment, when the effluent absorbance was equal to $10 \%$ of the saturation absorbance, sample loading was stopped (2). The total applied protein to the column per milliliter of resin was calculated by multiplying the time of application by the flow rate and the sample total protein concentration, and then dividing the result by the volume of resin. Total nonabsorbed protein per milliliter of resin was calculated by multiplying the protein concentration of flow through effluent by its volume, dividing by the resin volume. DBC was calculated as the total protein absorbed per milliliter of resin by subtracting the total nonabsorbed protein from total applied protein per milliliter of resin (31). Data for first and second run of each treatment are shown in Table 2.

\section{Discussion}

In the recent years, design of experiment (DOE) has been developed for synchronic analysis of parameters

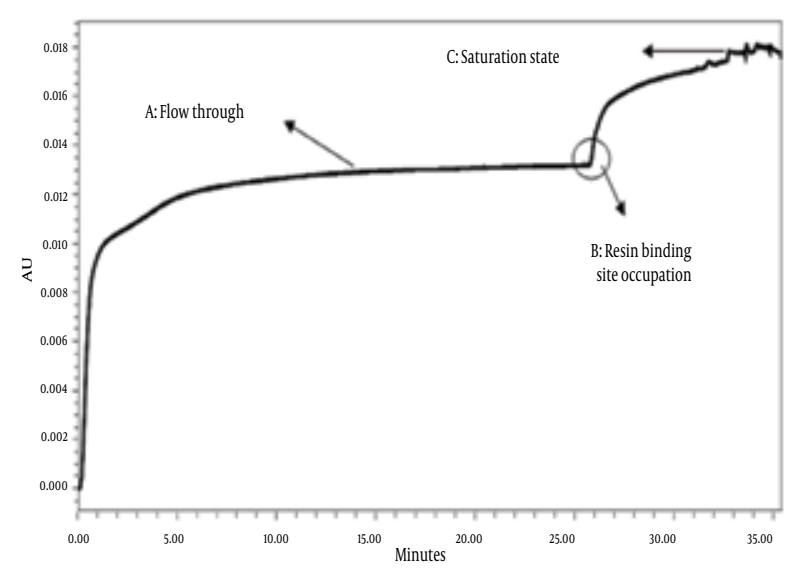

Figure 1. Chromatogram of Saturation State

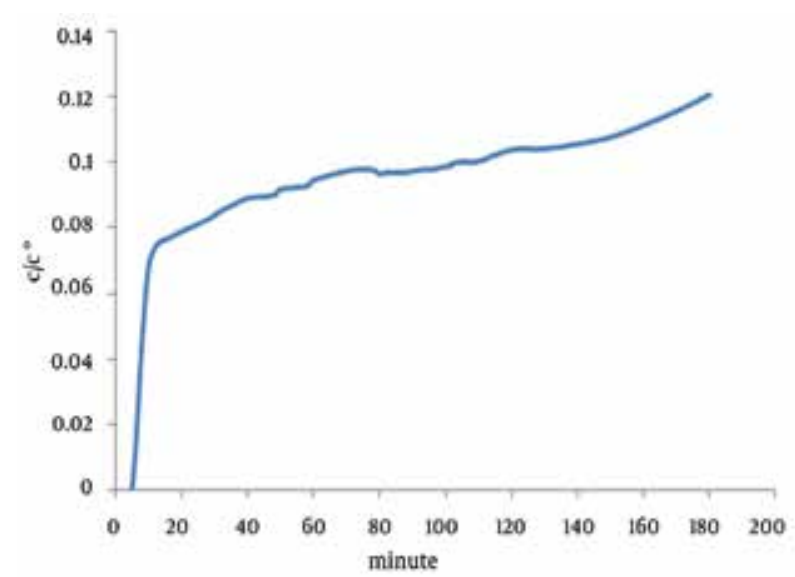

Figure 2. Breakthrough Curve of Treatment One

and variables. This experiment comprised a set of independent factors over a specific section of levels, leading to a successful optimization. Taguchi's methodology for designing parameters uses the orthogonal array, involving control variables. The signal-to-noise $(\mathrm{S} / \mathrm{N})$ ratio is the value that omits the noise or standard deviation factors, which cannot be controlled. This ratio is a measure of signal strength relative to the background noise. During investigating the optimum conditions for this experiment, the S/N ratio and analysis of variance (ANOVA) were applied to determine the best configurations of the optimized variables. In this study, the raw data were transformed into ratios of $\mathrm{S} / \mathrm{N}$ and measured as a log.S/N ratio is correlated to standard deviations of the results and is calculated as:

Equation 1: $\mathrm{S} / \mathrm{N}=-10 \log \mathrm{MSD}$

MSD: mean of standard deviations

Depending on the type of target, MSD is calculated by one of the following equations:

Target: 
Equation 2: a) Smaller is better

$$
\frac{\sum_{i=1}^{r} Y_{i}^{2}}{r}
$$

Equation 3: b) Larger is better

$$
\frac{\sum_{i=1}^{r}\left(\frac{1}{Y_{i}^{2}}\right)}{r}
$$

Equation 4: c) Closer is better

$$
\frac{\sum_{i=1}^{r}\left(Y_{i}-\mathrm{M}\right)^{2}}{r}
$$

Where: $\mathrm{Y}_{\mathrm{i}}$ : result; $\mathrm{r}$ : runs

For each treatment, the $\mathrm{S} / \mathrm{N}$ ratio was calculated according to equation 3, because our target was "larger DBC" and the results are shown in Table 3.
After calculating MSD and the $\mathrm{S} / \mathrm{N}$ ratio for each treatment, the $\mathrm{S} / \mathrm{N}$ ratio was used to prepare the table of main effects and for ANOVA analysis. There, all calculations were the same, but the target was the $\mathrm{S} / \mathrm{N}$ ratio and the condition was the larger, the better. Therefore, average of the $\mathrm{S} / \mathrm{N}$ ratio was calculated by calculating its average for all the levels of each factor. These results are shown in Table 4.

The main effect graph was then plotted for each level of each factor, shown in Figure 3.

The ANOVA technique was applied to measurethe experiments,such as orthogonal array. ANOVA and main effect graph show the optimum level for each factor. Levels with greater $\mathrm{S} / \mathrm{N}$ ratio were the optimum levels. In this case, A1, B2 and C3 were optimum conditions, meaning that maximum binding capacity was reached with a $\mathrm{pH}$ of 5 for the working buffer, $50 \mathrm{mg} / \mathrm{mL}$ for the protein feed concentration, and $120 \mathrm{~cm} / \mathrm{h}$ for the application flow rate. It was possible to calculate an expected amount for the $\mathrm{S} / \mathrm{N}$ ratio (Equations 5 and 6 ) and the target parameter (dy-

\begin{tabular}{|c|c|c|c|}
\hline pH & Linear Flow Rate $\left(\mathrm{cm} \cdot \mathrm{hr}^{-1}\right)$ & Protein Concentration $\left(\mu \mathrm{g} \cdot \mathrm{mL}^{-1}\right)$ & Treatment \\
\hline 5 & 60 & 50 & $\mathrm{~T} 1$ \\
\hline 6 & 120 & 50 & $\mathrm{~T} 2$ \\
\hline 7 & 240 & 50 & T3 \\
\hline 6 & 60 & 40 & $\mathrm{~T} 4$ \\
\hline 7 & 120 & 40 & T5 \\
\hline 5 & 240 & 40 & T6 \\
\hline 7 & 60 & 30 & T7 \\
\hline 5 & 120 & 30 & T8 \\
\hline 6 & 240 & 30 & T9 \\
\hline
\end{tabular}
namic binding capacity) by the Taguchi method, according to Equations 7-9.

\begin{tabular}{|c|c|c|c|c|c|}
\hline \multicolumn{2}{|c|}{ Treatment } & \multirow{2}{*}{$\begin{array}{c}\begin{array}{c}\text { Sample Volume, } \\
\text { mL }^{\text {b }}\end{array} \\
208\end{array}$} & \multirow{2}{*}{$\begin{array}{c}\begin{array}{c}\text { Total Applied Protein, } \\
\text { mg.mL }\end{array} \text { of Resin } \\
10.4\end{array}$} & \multirow{2}{*}{$\begin{array}{c}\begin{array}{c}\text { Total Nonabsorbed } \\
\text { Protein,mg.mL }\end{array} \text { of Resin } \\
2.496\end{array}$} & \multirow{2}{*}{$\begin{array}{c}\begin{array}{c}\text { DBC, mg.mL } \\
{ }^{1} \text { Resin }\end{array} \\
7.904\end{array}$} \\
\hline T1 & 1st run & & & & \\
\hline & 2nd run & 184 & 9.2 & 3.864 & 5.336 \\
\hline \multirow[t]{2}{*}{ T2 } & 1st run & 56 & 2.8 & 1.064 & 1.736 \\
\hline & 2nd run & 47.2 & 2.36 & 0.708 & 1.652 \\
\hline \multirow[t]{2}{*}{ T3 } & 1st run & 108 & 5.4 & 2.7 & 2.7 \\
\hline & 2nd run & 70.4 & 3.52 & 1.6896 & 1.8304 \\
\hline \multirow[t]{2}{*}{ T4 } & 1st run & 172 & 6.88 & 2.064 & 4.816 \\
\hline & 2nd run & 16 & 0.64 & 0.32 & 0.32 \\
\hline \multirow[t]{2}{*}{ T5 } & 1st run & 152 & 6.08 & 2.888 & 3.192 \\
\hline & 2nd run & 88 & 3.52 & 1.232 & 2.288 \\
\hline \multirow[t]{2}{*}{ T6 } & 1st run & 88 & 3.52 & 1.144 & 2.376 \\
\hline & 2nd run & 52.8 & 2.112 & 1.4784 & 0.6336 \\
\hline \multirow[t]{2}{*}{ T7 } & 1st run & 70 & 2.1 & 1.82 & 0.28 \\
\hline & 2nd run & 95 & 2.85 & 1.995 & 0.855 \\
\hline \multirow[t]{2}{*}{ T8 } & 1st run & 63.6 & 1.908 & 1.4628 & 0.4452 \\
\hline & 2nd run & 74 & 2.22 & 1.628 & 0.592 \\
\hline \multirow[t]{2}{*}{ T9 } & 1st run & 46.4 & 1.392 & 1.2992 & 0.0928 \\
\hline & 2nd run & 69.6 & 2.088 & 1.2528 & 0.8352 \\
\hline
\end{tabular}

Table 2. The Selected Levels for Three Factors (Concentration, Flow Rate and pH) According to an L9 Orthogonal Array and Dynamic Binding Capacity of 9 Treatments ${ }^{\text {a }}$

a Abbreviation: DBC, dynamic binding capacity.

b Sample was applied to the column up to $10 \%$ of the saturation state. 
Sepahi M et al.

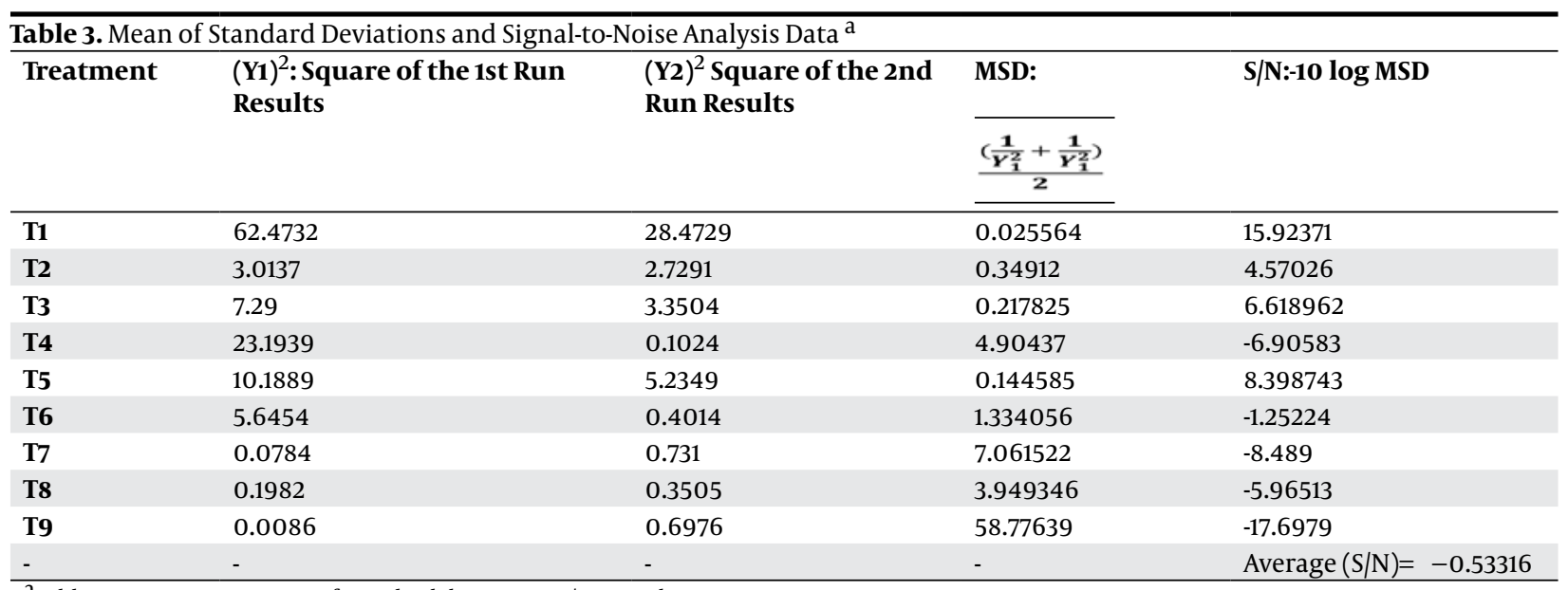

a Abbreviations: MSD, mean of standard deviations; S/N, signal-to-noise.

\begin{tabular}{|c|c|c|c|c|}
\hline Parameter & $\mathbf{S} / \mathbf{N}_{\mathrm{Mi}, 1}{ }^{\mathrm{a}}$ & $\mathbf{S} / \mathbf{N}_{\mathrm{Mi}, 2}$ & $\mathbf{S} / \mathbf{N}_{\mathrm{Mi}, 3}$ & S/N Average \\
\hline$M=A, i=1, A_{1}^{b}$ & 15.9237 & 4.5703 & 6.61896 & 9.037653 \\
\hline$M=A, i=2, A_{2}$ & -6.90583 & 8.39874 & -1.25224 & 0.080223 \\
\hline$M=A, i=3, A_{3}$ & -8.489 & -5.96513 & -17.6979 & -10.7173 \\
\hline $\mathbf{M}=\mathbf{B}, \mathbf{i}=\mathbf{1}, \mathbf{B}_{\mathbf{1}}$ & 15.9237 & -6.90583 & -8.489 & 0.17629 \\
\hline $\mathbf{M}=\mathbf{B}, \mathbf{i}=\mathbf{2}, \mathbf{B}_{2}$ & 4.5703 & 8.39874 & -5.96513 & 2.334637 \\
\hline$M=B, i=3, B_{3}$ & 6.61896 & -1.25224 & -17.6979 & -4.11039 \\
\hline $\mathbf{M}=\mathbf{C}, \mathbf{i}=\mathbf{1}, \mathbf{C}_{\mathbf{1}}$ & 15.9237 & -1.25224 & -5.96513 & 2.90211 \\
\hline$M=C, i=2, C_{2}$ & 4.5703 & -6.90583 & -17.6979 & -6.67781 \\
\hline$M=C, i=3, C_{3}$ & 6.61896 & 8.39874 & -8.489 & 2.176233 \\
\hline
\end{tabular}

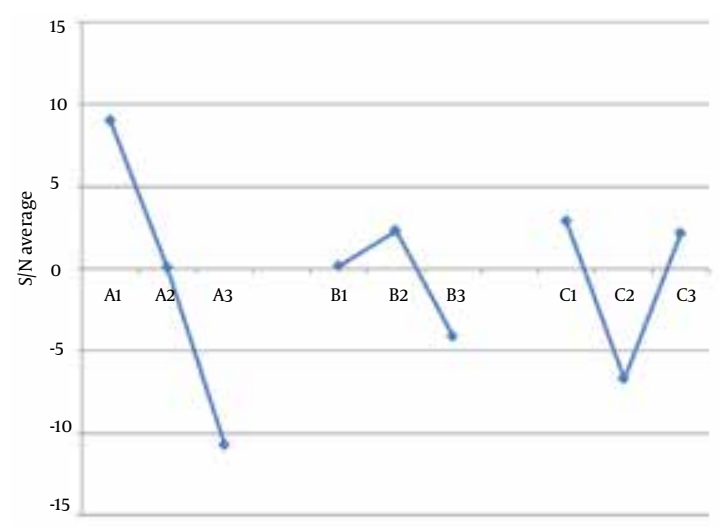

Figure 3. Main Effect of Each Level of Each Factor

\section{Equation 5:}

$$
\begin{aligned}
S / N_{\text {exp }}=\bar{T}+ & \left(\overline{S / N_{A-o p t}}-\bar{T}\right)+\left(\overline{S / N_{B-o p t}}-\bar{T}\right)+\left(\overline{S / N_{C-o p t}}-\bar{T}\right) \\
& =\overline{S / N_{A-o p t}}+\overline{S / N_{B-o p t}}+\overline{S / N_{C-o p t}}-2 \bar{T}
\end{aligned}
$$




\section{Equation 6:}

$$
\bar{T}=\frac{\sum(S / N)}{n}
$$

According to the Type of targets, equations for the expected targets are:

Equation 7: a) Smaller is better: $\mathrm{Y}_{\mathrm{exp}}=$

$$
\sqrt{\mathrm{MSD}_{\exp }}
$$

Equation 8: b) Larger is better: $\mathrm{Y}_{\exp }=$

$$
\sqrt{\frac{1}{\mathrm{MSD}_{\exp }}}
$$

Equation 9: c) Closer is better: to a certain amount $(\mathrm{M}): \mathrm{Y}_{\exp }=$

$$
\sqrt{\mathrm{MSD}_{\exp }}
$$

In this research:

$$
\begin{gathered}
S / N_{\text {exp }}=\overline{S / N_{A 1}}+\overline{S / N_{B 2}}+\overline{S / N_{C 3}}-2 \bar{T} \\
S / N_{\text {exp }}=9.037653+2.334637+2.90211-2 \times(-0.53316)= \\
15.34072 \\
Y_{\exp }=10^{-\frac{\frac{S}{N_{\exp }}}{10}}=10^{-1534072}=0.0292367 \\
Y_{\exp }=\sqrt{\frac{1}{\mathrm{MSD}}}=\sqrt{\frac{1}{0.0292367}} \cong 5.8484
\end{gathered}
$$

According to the treatments and performed experiments, $5.85 \mathrm{mg}$ protein per milliliter of resin was the maximum binding capacity for purification of recombinant EPO by anionic exchange chromatography, using QSFF resin. This criterion was used to perform an experiment (repeated three times). Measured dynamic binding capacities (6.208, 5.91, $6.054 \mathrm{mg} \cdot \mathrm{mL}^{-1}$ and mean: $6.0573 \mathrm{mg} / \mathrm{mL}$ ) were analyzed by one sample t-test and no significant difference was observed $(P=0.136)$.

\section{Acknowledgements}

We are grateful to other coworkers: R. Mardani, A.H. Majidi, L. Shafiee, and R. Khosravi at the Recombinant Biopharmaceutical Production Department of Institute Pasteure for their expert assistance.

\section{Authors' Contribution}

All the authors equallyparticipated in this research.

\section{Funding/Support}

Iran National Foundation of Science (INFS) provided financial support for research conduction and production, and Research Complex of Pasteur Institute of Iran provided the materials and equipment.

\section{Financial Disclosure}

There was no conflict of interest.

\section{References}

1. Determination of Dynamic Binding Capacity for ProSep-vA Media. Millipore Tech Pub. 2005;TB1175EN00.

2. Bergander T, Nilsson-Valimaa K, Oberg K, Lacki KM. Highthroughput process development: determination of dynamic binding capacity using microtiter filter plates filled with chromatography resin. Biotechnol Prog. 2008;24(3):632-9.

3. LeVan M, Carta G, Yon C. Perry's Chemical engineers Handbook Green DW editor. New York: McGraw-Hill; 1997.

4. Mönster A, Villain L, Scheper T, Beutel S. One-step-purification of penicillin $\mathrm{G}$ amidase from cell lysate using ion-exchange membrane adsorbers. J Memb Sci. 2013;444:359-64.

5. Pabst TM, Suda EJ, Thomas KE, Mensah P, Ramasubramanyan N Gustafson ME, et al. Binding and elution behavior of proteins on strong cation exchangers. J Chromatogr A. 2009;1216(45):7950-6.

6. Shapiro MS, Haswell SJ, Lye GJ, Bracewell DG. Design and characterization of a microfluidic packed bed system for protein breakthrough and dynamic binding capacity determination. Biotechnol Prog. 2009;25(1):277-85.

7. Staby A, Jensen IH. Comparison of chromatographic ion-exchange resins. II. More strong anion-exchange resins. J Chromatogr A. 2001;908(1-2):149-61.

8. 3 ed: Pharmacia LKB Biotechnology; 1991.

9. Hofer S, Ronacher A, Horak J, Graalfs H, Lindner W. Static and dy namic binding capacities of human immunoglobulin $\mathrm{G}$ on polymethacrylate based mixed-modal, thiophilic and hydrophobic cation exchangers. J Chromatogr A. 2011;1218(49):8925-36.

10. Ahamed T. Netherland: Delft university of Technology; 2008.

11. Carta G. Predicting protein dynamic binding capacity from batch adsorption tests. Biotechnol J. 2012;7(10):1216-20.

12. Sofer GK, Hagel L. illustrated ed: Academic Press; 1997.

13. Bhambure R, Kumar K, Rathore AS. High-throughput process development for biopharmaceutical drug substances. Trends Biotechnol. 2011;29(3):127-35.

14. Shukla AA, Etzel MR, Gadam S. Process scale bioseparations for the biopharmaceutical industry. Springer. 2007.

15. Sofer G, Chirica LC. Downstream Processing: Improving Productivity in Downstream Processing. Biopharm international. 2006;19(11).

16. Faude A, Zacher D, Muller E, Bottinger H. Fast determination of conditions for maximum dynamic capacity in cation-exchange chromatography of human monoclonal antibodies. J Chromatogr A. 2007;1161(1-2):29-35.

17. Hahn R, Schulz PM, Schaupp C, Jungbauer A. Bovine whey fractionation based on cation-exchange chromatography. J Chromatogr A. 1998;795(2):277-87.

18. Harinarayan C, Mueller J, Ljunglof A, Fahrner R, Van Alstine J, van Reis R. An exclusion mechanism in ion exchange chromatography. Biotechnol Bioeng. 2006;95(5):775-87.

19. Lendero N, Vidic J, Brne P, Podgornik A, Strancar A. Simple method for determining the amount of ion-exchange groups on chromatographic supports. J Chromatogr A. 2005;1065(1):29-38.

20. Urmann M, Graalfs H, Joehnck M, Jacob LR, Frech C. Cation-exchange chromatography of monoclonal antibodies: Characterisation of a novel stationary phase designed for production-scale 
purification. MAbs. 2010;2(4).

21. Levison PR, Jones RMH, Toome DW, Badger SE, Streater M, Pathirana ND. Influence of flow-rate on the chromatographic performance of agarose-and cellulose-based anion-exchange media. $J$ Chromatogr A. 1996;734(1):137-43.

22. Martin C, Coyne J, Carta G. Properties and performance of novel high-resolution/high-permeability ion-exchange media for protein chromatography.J Chromatogr A. 2005;1069(1):43-52.

23. Sheth B. Characterisation of chromatography adsorbents for antibody bioprocessing. UCL (University College London); 2009.

24. Roy R. A primer on the Taguchi method. Van Nostrand Reinhold; 1990.

25. Yuen CT, Storring PL, Tiplady RJ, Izquierdo M, Wait R, Gee CK, et al. Relationships between the N-glycan structures and biological activities of recombinant human erythropoietins produced using different culture conditions and purification procedures. $\mathrm{Br}$
J Haematol. 2003;121(3):511-26.

26. Simonian MH, Smith JA. Spectrophotometric and colorimetric determination of protein concentration. Curr Protoc Mol Biol. 2006; Chapter 10:Unit 10 1A.

27. Mihelic I, Podgornik A, Koloini T. Temperature influence on the dynamic binding capacity of a monolithic ion-exchange column. J Chromatogr A. 2003;987(1-2):159-68.

28. Shukla AMRE, Shishir G. Taylor \& Francis Group; 2007.

29. Hunter AK, Carta G. Protein adsorption on novel acrylamidobased polymeric ion-exchangers. III. Salt concentration effects and elution behavior. J Chromatogr A. 2001;930(1-2):79-93.

30. Ljunglof A, Lacki KM, Mueller J, Harinarayan C, van Reis R, Fahrner R, et al. Ion exchange chromatography of antibody fragments. Biotechnol Bioeng. 2007;96(3):515-24.

31. Endo I, Nagamune T, Katoh S, Yonemoto T. Bioseparation and bioengineering: progress in Biotechnology. Elsevier Scie B.V. 2000. 